\title{
YEASTS ISOLATED FROM SAND AND SEA WATER IN BEACHES OF OLINDA, PERNAMBUCO STATE, BRAZIL
}

\author{
Silvia Tereza Azedo Loureiro ${ }^{1}$; Maria Auxiliadora de Queiroz Cavalcanti ${ }^{1}$; Rejane Pereira Neves ${ }^{1}$; \\ José Zanon de Oliveira Passavante ${ }^{2}$
}

\begin{abstract}
${ }^{1}$ Departamento de Micologia, Centro de Ciências Biológicas, Universidade Federal de Pernambuco, PE, Brasil; ${ }^{2}$ Departamento de Oceanografia, Universidade Federal de Pernambuco, PE, Brasil
\end{abstract}

Submitted: November 19, 2004; Returned to authors for corrections: February 15, 2005; Approved: November 13, 2005

\begin{abstract}
The aim of this work was to isolate and identify yeasts from sand and sea water collected in two beaches of Olinda, Pernambuco state, Brazil. Thirty two samples of both sand and water in both beaches were obtained in the dry (December 2000 and February 2001) and rainy (June and July 2001) seasons. Two hundred and ninety two strains of yeast were obtained, and they belonged to four genera and 31 species. Candida was the most prevalent genus. Candida catenulata, C. fenica, C. sake, Brettanomyces bruxelenses and Rhodotorula mucilaginosa were the most commonly found species in both beaches Bairro Novo and Casa Caiada.
\end{abstract}

Key words: yeast, sand, water, beaches

\section{INTRODUCTION}

There is a great interest on increasing the knowledge regarding fungi in marine ecosystems, considering the small number of species known in this environment in Brazil, a country with a large coastal area.

Most of the studies referring to the isolation of yeasts from estuary waters and marine areas have been done in Europe and North America and only a few in South American countries like Chile and Brazil $(5,7,25,26)$. In South Florida marine waters, highly polluted by domestic wastes, species of Candida, Trichosporon, Torulopsis and Rhodotorula were detected $(13,22)$. These last two species are usually observed in marine environments $(1,23)$ and, in the coastal region of Florida, Rhodotorula, Candida and Debaryomyces are the most commonly found species (2).

In Brazil, studies about yeasts isolated from sea water began in Florianópolis (11) and later in Recife (27) and Rio de Janeiro $(14,15,16)$. Studies in São Paulo have shown that species of Candida can be used as indicators of pollution in marine estuaries (24). The aim of this work was to isolate and identify yeasts from sand and sea water in two beaches of Olinda, Pernambuco State, Brazil.

\section{MATERIALS AND METHODS}

Collection area - The Bairro Novo Beach, located in Olinda, Pernambuco State, Brazil, is approximately $2 \mathrm{~km}$ long, and has costal protection against erosion caused by sea invasion. This protection comprises nearly 36 perpendicular menmade reefs of $50 \mathrm{~m}$, separated $50 \mathrm{~m}$ from each other. Besides marine erosion, many environmental problems are found in this beach, including domestic wastes and solid residues going into the sea, making the water inappropriate for bathing and water sports (6).

Casa Caiada is an urban beach, also located in Olinda, Pernambuco State, Brazil, and has approximately $4.5 \mathrm{Km}$ of extension. This beach presents calm waters and some menmade reefs, being used for bathing, soccer practice and water sports (windsurf, swimming, sailing, and others), as well as for fishing and mollusk capture. The main environmental problems found there are precipitation, disposal of domestic wastes and solid residues.

\section{Physical chemical and climatic parameters}

The $\mathrm{pH}$ and the temperature of sand and sea water were determined using a digital pHmeter and a digital thermometer

*Corresponding Author. Mailing address: Av. Boa Viagem, 3376, Boa Viagem, 51020-001, Recife, PE, Brasil. E-mail: xiliamac@terra.com.br 
(Hanna), respectively. Pluviometric data from the city of Olinda were provided by the Empresa Pernambucana de Pesquisa Agropecuária (IPA) and by the Secretaria de Recursos Hídricos de Pernambuco (SRH). Colorimetric water analysis was provided by the Companhia Pernambucana de Controle de Poluição Ambiental e da Administração dos Recursos Hídricos (CPRH), who also informed the most probable number (NMP) of fecal coliform bacteria and the classification of the sea water according to regulations of CONAMA, Brazil. The climate in Olinda is hot and humid, with spring and winter rains distributed from March to August. By the time of this study, the lowest temperature in the coldest month was in $18^{\circ} \mathrm{C}$.

\section{Sampling}

Samples of sand and sea water in both beaches were obtained in the dry (December 2000 and February 2001) and rainy (June and July 2001) seasons. Thirty two samples were obtained from sand and thirty two from sea water, in low water and sysygy tide, based on tide tables of Recife Harbor, Pernambuco State (8). Water salinity was determined in a manual refractometer (Atago). Sand was collected with a garden shovel, in the region of medium seashore, at $1 \mathrm{~m}$ from the tide line, at the surface and also $20 \mathrm{~cm}$ deep. The samples were kept in plastic bags. Sea water was collected at the surface and at $1 \mathrm{~m}$ deep, using sterilized glass tubes. All samples were maintained at room temperature and transferred to the laboratory, in the Department of Mycology of Universidade Federal de Pernambuco, for immediate testing.

\section{Cultures isolation, purification and identification}

From each sample, a suspension of $50 \mathrm{~g}$ of sand in $90 \mathrm{~mL}$ of sterilized destilled water was prepared and $0.5 \mathrm{~mL}$ of this suspension were placed in Petri dishes in triplicate containing Sabouraud Dextrose Agar added of Yeast Extract and Cloranfenicol $(18,26)$.

For isolation of fungi, $0.5 \mathrm{~mL}$ of sea water were placed on the surface of the same medium, in Petri dishes, which were prepared in triplicate and maintained at room temperature $\left(28^{\circ} \mathrm{C} \pm 1^{\circ} \mathrm{C}\right)$. The colonies were transferred to glass tubes containing Sabouraud Dextrose Agar and Yeast Extract, and submitted to macroscopic, microscopic and physiological observations $(4,17,19)$.

Table 1. Species of yeasts isolated from seawater of the Bairro Novo beach, Pernambuco, Brazil, during the dry and rainy seasons.

\begin{tabular}{|c|c|c|c|c|c|c|c|c|c|c|c|c|c|c|c|c|}
\hline \multirow[t]{2}{*}{$\begin{array}{l}\text { GENERA/ } \\
\text { SPECIES }\end{array}$} & \multicolumn{4}{|c|}{$\begin{array}{c}\text { DRY } \\
\text { LOW WATER }\end{array}$} & \multicolumn{4}{|c|}{$\begin{array}{c}\text { DRY } \\
\text { SYSYGY TIDE }\end{array}$} & \multicolumn{4}{|c|}{$\begin{array}{c}\text { RAINY } \\
\text { LOW WATER }\end{array}$} & \multicolumn{4}{|c|}{$\begin{array}{c}\text { RAINY } \\
\text { SYSYGYTIDE }\end{array}$} \\
\hline & SS & $\mathrm{SD}$ & SW & DW & SS & $\mathrm{SD}$ & SW & DW & SS & SD & SW & DW & SS & SD & SW & DW \\
\hline $\begin{array}{l}\text { Brettanomyces bruxellensis } \\
\text { Kufferath \& van Laer }\end{array}$ & $\mathrm{x}$ & - & - & $\mathrm{x}$ & - & - & - & - & $\mathrm{x}$ & - & - & - & - & - & - & - \\
\hline $\begin{array}{l}\text { Candida bombicola } \\
\text { (Spencer et al.) Meyer \& Yrrow }\end{array}$ & - & - & - & - & - & - & - & $\mathrm{x}$ & - & - & - & - & - & - & - & - \\
\hline C. catenulata Diddens \& Lodder & - & - & - & - & - & $\mathrm{x}$ & - & $\mathrm{x}$ & - & - & - & - & - & - & - & - \\
\hline $\begin{array}{l}\text { C. diddensiae (Phaff et al.) } \\
\text { Fell \& Meyer }\end{array}$ & - & - & - & - & - & - & - & - & - & - & - & - & - & - & $\mathrm{x}$ & - \\
\hline C. fennica Meyer \& Ahearn & - & - & - & - & - & - & - & - & - & - & $\mathrm{x}$ & - & $\mathrm{x}$ & - & - & - \\
\hline $\begin{array}{l}\text { C. geochares (van der Walt } \\
\text { et al.) Meyer \& Yarrow }\end{array}$ & - & - & - & - & - & - & $\mathrm{x}$ & - & - & - & - & - & - & - & - & - \\
\hline $\begin{array}{l}\text { C. melibiosica } \text { Buckley } \\
\& \text { vanUden }\end{array}$ & $\mathrm{x}$ & - & - & - & - & - & - & - & - & - & - & - & - & - & - & $\mathrm{x}$ \\
\hline C. palmioleophila Nakase \& Itoh & - & - & - & - & - & - & - & $\mathrm{x}$ & - & - & - & - & - & - & - & - \\
\hline C. pseudolambica Smith et al. & - & - & - & - & - & - & - & - & - & - & - & - & - & - & - & $\mathrm{x}$ \\
\hline C. rhagii Jurzita et al. & - & - & - & - & - & - & - & - & - & - & - & $\mathrm{x}$ & $\mathrm{x}$ & - & - & - \\
\hline C. saitoana Nakase ( Suzuki) & - & - & - & - & - & - & $\mathrm{x}$ & - & - & - & - & - & - & - & - & - \\
\hline $\begin{array}{l}\text { C. sake Saito van Uden Buckley } \\
\text { (Meyer \& Ahearn) }\end{array}$ & - & - & - & - & - & - & - & - & - & $\mathrm{x}$ & - & - & - & - & - & - \\
\hline C. vaccinii Tokuoka et al. & - & - & - & - & - & - & - & - & - & $\mathrm{x}$ & - & - & - & - & - & - \\
\hline $\begin{array}{l}\text { Rhodotorula ingeniosa } \\
\text { (di Menna) von Arx \& Weijiman }\end{array}$ & - & - & - & - & - & - & - & - & - & - & - & - & - & - & - & $\mathrm{x}$ \\
\hline $\begin{array}{l}\text { R. mucilaginosa } \\
\text { (Jörgensen) Harrison }\end{array}$ & $\mathrm{x}$ & - & - & - & - & - & - & - & - & - & - & - & - & - & - & $\mathrm{x}$ \\
\hline
\end{tabular}

SS = Sand Surface, $\mathrm{SD}=$ Sand at 20cm Deep, $\mathrm{SW}=$ Surface Water, DW = Deep Water. 


\section{Frequency of the yeasts species}

The frequency of each yeast species was calculated according to Dajoz (10), with modifications, using the formula: $\mathrm{Fo}_{\mathrm{O}}=\mathrm{Ta} .100 / \mathrm{TA}$, where $\mathrm{Ta}=$ number of samples in which the taxon occurred and TA = total number of samples. According to this formula, the frequencies of the species were classified as: $<$ $10 \%=$ rare $; 10 \leq 25 \%=$ low $25<35 \%=$ frequent $35<50 \%=$ abundant, and $>50 \%=$ very abundant.

\section{RESULTS AND DISCUSSION}

\section{Hydrologic parametrs, pH, temperature and salinity of sand and sea water}

The water temperature in both beaches varied from $24.3^{\circ} \mathrm{C}$ in December to $29.4^{\circ} \mathrm{C}$ in February. On the most rainy month (July) the water temperature was $25.3^{\circ} \mathrm{C}$ minimum and $28.2^{\circ} \mathrm{C}$ maximum.
The sand temperature in the dry season varied from $25.7^{\circ} \mathrm{C}$ in December to $29.4^{\circ} \mathrm{C}$ in February, and in July varied from $24.4^{\circ} \mathrm{C}$ to $28.8^{\circ} \mathrm{C}$. The $\mathrm{pH}$ of all samples was slightly alkaline, ranging from 7.6 to 8.2. In Bairro Novo Beach the salinity in water and sand varied from $20 \%$ in the rainy season to $40 \%$ in the dry season, while in Casa Caiada Beach varied from $24 \%$ o to $39 \%$ in the same seasons.

\section{Isolation and identification of yeasts}

Thirty one species of yeasts were isolated, and nineteen belonged to the genus Candida. In the Bairro Novo Beach, 15 species were isolated, belonging mostly to Candida (twelve), Rhodotorula (two) and Brettanomyces (one) genera. In the Casa Caiada Beach, 21 species were identified: Candida was also the most common genus (10 species), followed by Trichosporon, Rhodotorula and Brettanomyces, respectively with five, three and three species (Tables 1 and 2).

Table 2. Species of yeasts isolated from seawater of the Casa Caiada beach, Pernambuco, Brazil, during the dry and rainy seasons.

\begin{tabular}{|c|c|c|c|c|c|c|c|c|c|c|c|c|c|c|c|c|}
\hline \multirow[t]{2}{*}{$\begin{array}{l}\text { GENERA/ } \\
\text { SPECIES }\end{array}$} & \multicolumn{4}{|c|}{$\begin{array}{c}\text { DRY } \\
\text { LOW WATER }\end{array}$} & \multicolumn{4}{|c|}{$\begin{array}{c}\text { DRY } \\
\text { SYSYGY TIDE }\end{array}$} & \multicolumn{4}{|c|}{$\begin{array}{c}\text { RAINY } \\
\text { LOW WATER }\end{array}$} & \multicolumn{4}{|c|}{$\begin{array}{c}\text { RAINY } \\
\text { SYSYGYTIDE }\end{array}$} \\
\hline & SS & SD & SW & DW & SS & SD & SW & DW & SS & $\mathrm{SD}$ & SW & DW & SS & $\mathrm{SD}$ & SW & DW \\
\hline Brettanomyces anomalus Custers & - & - & $\mathrm{x}$ & - & - & - & - & - & - & - & - & - & - & - & - & - \\
\hline $\begin{array}{l}\text { B. bruxellensis Kufferath } \\
\text { \& van Laer }\end{array}$ & $\mathrm{x}$ & - & - & - & - & $\mathrm{x}$ & - & - & $\mathrm{x}$ & - & - & - & - & - & - & - \\
\hline B. custersianus van der Walt & $\mathrm{x}$ & - & - & - & - & - & - & - & - & - & - & - & - & - & - & - \\
\hline $\begin{array}{l}\text { Candida albicans } \\
\text { (Robin) Berkhout }\end{array}$ & - & $\mathrm{x}$ & - & - & - & - & - & - & - & - & - & - & - & - & - & - \\
\hline C.blankii Buckley \& van Uden & - & - & - & - & - & - & - & - & - & - & $\mathrm{x}$ & - & - & - & - & - \\
\hline C. catenulata Diddens \& Lodder & - & - & - & $\mathrm{x}$ & $\mathrm{x}$ & - & - & - & - & - & - & - & - & - & - & $\mathrm{x}$ \\
\hline C. fennica Meyer \& Ahearn & - & - & - & - & - & - & - & - & - & - & - & $\mathrm{x}$ & - & - & - & - \\
\hline C. intermedia Cifferri \& Ashford & - & - & - & - & - & - & - & - & - & - & - & - & $\mathrm{x}$ & - & - & - \\
\hline C. maltosa Komagata et al. & - & - & - & - & $\mathrm{x}$ & - & - & - & - & - & - & - & - & - & - & - \\
\hline C. milleri Yarrow & - & - & - & - & - & - & - & $\mathrm{x}$ & - & - & - & - & - & - & - & - \\
\hline C. parapsilosis Lamgeron \& Talice & - & - & - & - & - & - & - & - & $\mathrm{x}$ & - & - & - & - & - & $\mathrm{x}$ & - \\
\hline C. rugopelliculosa Nakase & $\mathrm{x}$ & - & - & - & $\mathrm{x}$ & - & - & - & - & - & - & - & - & - & - & - \\
\hline $\begin{array}{l}\text { C. sake Saito \& van Uden } \\
\text { Buckley (Meyer \& Ahearn) }\end{array}$ & $\mathrm{x}$ & - & - & - & - & - & - & - & - & - & - & - & $\mathrm{x}$ & - & - & - \\
\hline $\begin{array}{l}\text { Rhodotorula glutinis } \\
\text { (Fresenius) Harrison }\end{array}$ & - & - & - & - & - & - & - & - & $\mathrm{x}$ & - & - & - & - & - & - & - \\
\hline R. minuta (Saito) Harrison & - & - & - & - & - & $\mathrm{x}$ & - & - & - & - & - & - & - & - & - & - \\
\hline $\begin{array}{l}\text { R. mucilaginosa } \\
\text { (Jörjensen) Harrison }\end{array}$ & - & - & - & - & - & - & - & - & - & - & - & - & $\mathrm{x}$ & - & - & - \\
\hline $\begin{array}{l}\text { Trichosporon adeninovorans } \\
\text { Hiddelhven et al. }\end{array}$ & $\mathrm{x}$ & - & - & - & - & - & - & - & - & - & - & - & - & - & - & - \\
\hline T. aquatile Henderick \& Dupont & $\mathrm{x}$ & - & - & - & - & - & - & - & - & - & - & - & - & - & - & - \\
\hline $\begin{array}{l}\text { T. beigelii (Küchenmeiter) } \\
\text { Rabenhorst }\end{array}$ & - & - & - & - & - & - & - & - & $\mathrm{x}$ & - & - & - & - & - & - & - \\
\hline T. dulcitum (Berkhout) Weijiman & - & - & - & - & - & - & - & - & $\mathrm{x}$ & - & - & - & $\mathrm{x}$ & - & - & - \\
\hline T.lutetiae Saëz & - & - & - & - & - & - & - & - & - & - & - & - & $\mathrm{x}$ & - & - & - \\
\hline
\end{tabular}

$\mathrm{SS}=$ Sand Surface, $\mathrm{SD}=$ Sand at $20 \mathrm{~cm}$ Deep, $\mathrm{SW}=$ Surface Water, $\mathrm{DW}=$ Deep Water . 
Candida catenulate, C. fennica, C. sake, Brettanomyces bruxelensis and Rhodotorula mucilaginosa were the most commonly found species in both beaches. According to Fell and van Uden, 1963, species of Candida were dominant in marine environments in Florida (13). Five species of Trichosporon were isolated from sand at the Casa Caiada Beach. Paula et al., 1983, referred the low adaptation of Trichosporon to sea water in "Baixada Santista", São Paulo State (24). Two studies reported that Rhodotorula species occur in marine waters polluted by domestic wastes $(15,22)$. In our study, Brettanomyces was represented by three species. This genus was also frequently isolated from beach sand in Chile (25). It is possible that the yeasts found in the beaches of Bairro Novo and Casa Caiada have been brought not only by leaching but also by pluvial water and domestic wastes released along the beaches.

Pinto et al (26) referred that the rain precipitation affects significantly the frequency of fungi in sea water and sand, because, after raining the number of fungi is higher than during the dry season. In Olinda, the rain precipitation was $260.9 \mathrm{~mm}$ in June and $206.3 \mathrm{~mm}$ in July, and the amount of yeasts isolated during the rainy season was higher than that found in the dry period, when $180.5 \mathrm{~mm}$ and $43.25 \mathrm{~mm}$ of precipitation were registered in December and February, respectively.

Populations of yeasts in coastal waters are formed by various genera such as Candida, Trichosporon, Rhodotorula, Cryptococcus, Debaryomyces and Pichia $(22,23,27)$. The first

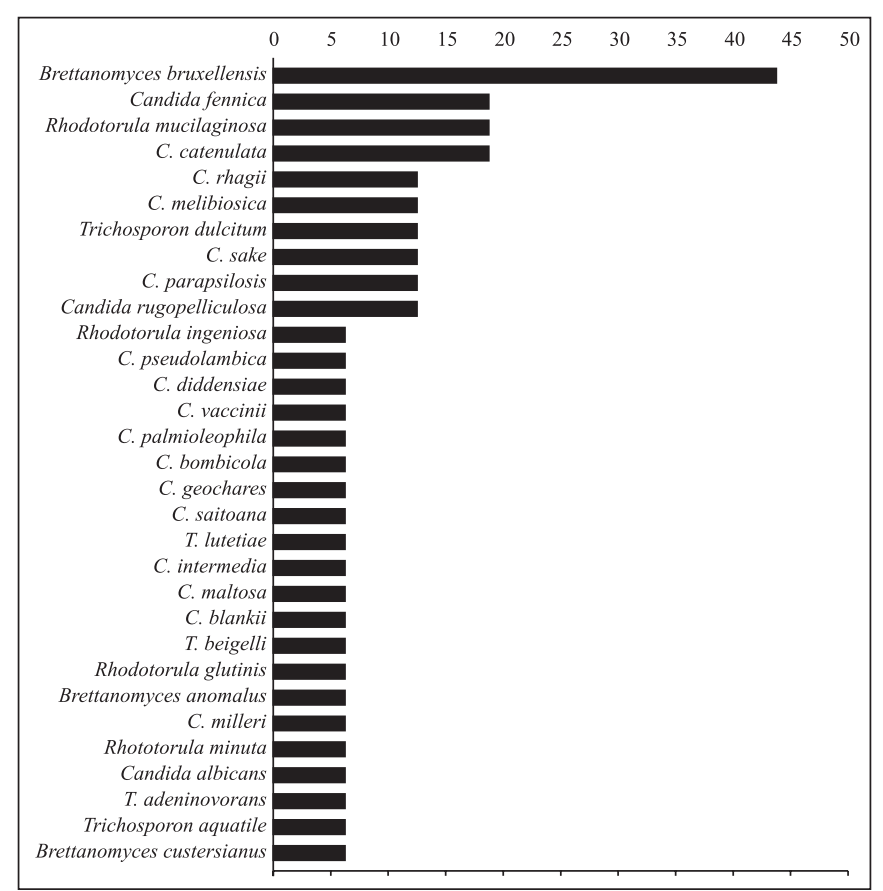

Figure 1. Frequency of occurrence (\%) of yeasts isolated in beaches of Bairro Novo and Casa Caiada, Olinda, Pernambuco. three were isolated from Bairro Novo e Casa Caiada beaches. Candida parapsilosis detected in this study is more common in human tissues, animal excrements, food products and drinks (20). Only one sample of $C$. albicans was isolated in Casa Caiada Beach, during the dry season, in low tide, and temperature of $29.4^{\circ} \mathrm{C}$. Anderson (3) mentioned that temperature affects growth of some Candida species isolated from marine environments, including C. albicans $(9,13,21)$.

Brettanomyces bruxellensis and C. fennica presented the highest numbers of colony forming units in the beaches of Bairro Novo and Casa Caiada, 58 and $65 \mathrm{CFU} / \mathrm{g}$, respectively (Table 3).

Table 3. Counts of yeasts (CFU/g) in water and sand samples of the Bairro Novo and Casa Caiada beachs.

\begin{tabular}{|c|c|c|c|c|c|}
\hline \multirow[t]{2}{*}{ Yeasts Species } & \multicolumn{2}{|c|}{ Casa Caiada } & \multicolumn{2}{|c|}{ Bairro Novo } & \multirow{2}{*}{ Tota } \\
\hline & Sand & Water & Sand & Water & \\
\hline Brettanomyces anomalu & $s-$ & - & 2 & - & 2 \\
\hline B. bruxellensis & 2 & 2 & 50 & 4 & 58 \\
\hline B. custersianus & - & - & 3 & - & 3 \\
\hline Candida albicans & - & - & 2 & - & 2 \\
\hline C. blankii & 1 & - & - & - & 1 \\
\hline C. bombicola & - & 6 & - & - & 6 \\
\hline C. catenulata & 9 & - & 1 & - & 10 \\
\hline C. diddensiae & - & 1 & - & - & 1 \\
\hline C. fennica & 3 & 2 & - & 60 & 65 \\
\hline C. geochares & - & 6 & - & - & 6 \\
\hline C. intermedia & - & - & 1 & - & 1 \\
\hline C. maltosa & - & - & 1 & - & 1 \\
\hline C. melibiosica & - & 1 & 2 & - & 3 \\
\hline C. milleri & 1 & - & - & - & 1 \\
\hline C. palmioleophila & - & 8 & - & - & 8 \\
\hline C. parapsilosis & 16 & - & 3 & - & 19 \\
\hline C. pseudolambica & - & 11 & - & - & 11 \\
\hline C. rhagii & - & 3 & - & 32 & 35 \\
\hline C. rugopelliculosa & - & - & 6 & - & 6 \\
\hline C. saitoana & - & 1 & - & - & 1 \\
\hline C. sake & - & - & 20 & 3 & 23 \\
\hline C. vaccinii & - & - & 2 & - & 2 \\
\hline Rhodotorula glutinis & - & - & 2 & - & 2 \\
\hline R. ingeniosa & - & 2 & - & - & 2 \\
\hline R. minuta & - & - & 1 & - & 1 \\
\hline R. mucilaginosa & - & 1 & 5 & 1 & 7 \\
\hline $\begin{array}{l}\text { Thichosporon } \\
\text { adeninovorans }\end{array}$ & - & - & 1 & - & 1 \\
\hline T. aquatile & - & - & 8 & - & 8 \\
\hline T. beigelii & - & - & 2 & - & 2 \\
\hline T. dulcitum & 1 & - & 2 & - & 3 \\
\hline T. lutetiae & - & - & 1 & - & 1 \\
\hline Total & 33 & 44 & 115 & 100 & 292 \\
\hline
\end{tabular}




\section{Yeasts frequency}

Brettanomyces bruxellensis presented the highest frequency $(43.75 \%)$, and was abundant in both beaches Candida catenulata, C. fennica and Rhodotorula mucilaginosa represented $18.75 \%$ of the isolations. C. melibiosica, $C$. parapsilosis, C. rhagri, C. rugopelliculosa, C. sake and Trichosporon dulcitum were considered species of low frequency $(12.75 \%)$ and the remaining species presented rare frequency (6.25\%) (Fig. 1). Brettanomyces bruxellensis was abundant in the sand of both beaches. The diversity of yeasts in Bairro Novo and Casa Caiada beaches is represented by species of Candida, Brettanomyces, Rhodotorula and Trichosporon.

\section{RESUMO}

\section{Leveduras isoladas do solo e da água do mar das praias de Bairro Novo e Casa Caiada, Olinda, Pernambuco, Brasil}

Com o objetivo de isolar e identificar leveduras do solo e água do mar das praias de Bairro Novo e Casa Caiada, Olinda, Pernambuco, Brasil, foram coletadas 32 amostras de solo e água em ambas as praias durante o período seco (dezembro/2000 e fevereiro/2001) e período chuvoso (junho e julho/2001). Foram obtidas 292 amostras de leveduras, distribuídas em quatro gêneros e 31 espécies. Candida apresentou maior número de espécies. Candida catenulata, C. fenica, C. sake, Brettanomyces bruxellensis e Rhodotorula mucilaginosa foram as espécies mais comuns em ambas as praias Bairro Novo e Casa Caiada.

Palavras-chave: leveduras, solo, água, praias

\section{REFERENCES}

1. Ahearn, D.G.; Roth Jr.; F.J.; Meyers, S.P. A comparative study of marine and terrestrial strains of Rhodotorula. Can J. Microbial., 8, 121-132, 1962.

2. Ahearn, D.G.; Roth Jr.; F.J.; Meyers, S.P.; Nichols, R.A. Extracellular proteinases of yeast and yeast - like fungi. Appl. Microbiol., 16, 1370-1374, 1968.

3. Anderson, J.H. In vitro suevival of human pathogenic fungi in seawater. Abouraudia, 17, 1-12, 1979.

4. Barnett, J.A.; Paine, R.W.; Yarrow, D. YEASTS: characteristics and Identification. 4ed. Cambridge, Cambridge: University Press 1990, 1002p.

5. Barbosa, A.M.B. Variação espaço - temporal da abundância e biomassa bacteriana no sistema lagunar Ria Formosa. M. Sc. Theses. University of Algarve, Portugal, 1989.
6. Beltrão, A.L.; Maia, J.T.A.; Oliveira, M.L. Diagnóstico Ambiental de Olinda, Recife: CPRH, 1985, 160p.

7. Borrego, J.J.; Arrabal, F.; de Vicente, A.; Gomez, L. F.; Romero, P. Study of microbial inactivation in the marine environment. J. Water Pollut. Control Fed. 55, 297-302, 1983.

8. Brasil - Diretoria de Hidrografia e Navegação. Tábuas de marés para 1999. Niterói, 1999, 194 p.

9. Buck, J.D. Candida albicans, Bacterial Indicators, Health hazards Associated with water, ASTMSTP 635. A.W. Hoadley and B.J. Dutka, Eds. American Society for Testing and Materials. 1977, p. $139-47$

10. Dajoz, R. Ecologia geral. 41 ed. Petrópolis: Vozes, 1983, 472p.

11. Faraco, B.F.C.; Faraco, B.A. Poluição hídrica micológica. Rev. Bras. Med., 33, 210-220, 1960.

12. Fell, J.W.; Ahearn, D.G.; Meyers, S.P.; Roth Jr., F.J. Isolation of yeasts from Biscayne Bay, Florida, and adjacent benthic areas Limnol. Oceanogr., 5, 366-371, 1960.

13. Fell, J.W.; van Uden, N. Yeasts in marine environments. In: Oppenheimer, C.H. - Symposium on Marine Microbiology. Springfield, Charles C. Thomas, p. 329-340, 1963.

14. Hagler, A.N. Ecologia e Taxonomia de leveduras em um Estuário e Ambientes Marinhos do Rio de Janeiro D. Sc Thesis, UFRJ. Rio de janeiro 1978, $400 \mathrm{p}$.

15. Hagler, A.N. and L.C. Mendonça-Hagler. Yeasts from marine and a estuarine waters with different levels of pollution in the state of Rio de Janeiro, Brazil. Appl. Environ. Microbiol., 41(1), 173-178, 1981.

16. Hagler, A.N.; Oliveira, R.B. de; Mendonça-Hagler, L.C. Yeasts in the intertidal sediments of a polluted estuary in Rio de Janeiro, Brasil. Antonie van Leeuvenhoek J. Microbial., 48, 53-56, 1982.

17. Kreger-van Rij, N.J.W. The yeast: a taxonomic study. 3 ed Elsevier Sci. Publi: Amsterdan, 1984, 1091 p.

18. Lacax, C.S.; Porto, C.; Martins, J.E.C.; Hlins-Vaccri, E.M.; Melo, N.K. Tratado de Micologia Médica. $9^{a}$ ed. Sarvier, São Paulo, 2002, $1104 \mathrm{p}$.

19. Lodder, J. The Yeast: a taxonomic study. Oxford: North Holland Publishing Company, 1970, 1385p.

20. Marrie, T.J.; Cooper, H.J.; Coster Ton, J.W. Ultrastructure of Candida parapsilosis endocarditis. Infect. Immun., 45, 390-398, 1984.

21. Meyers, S.P.; Ahearn, D.G.; Grunkel, W.; Roth Jr., F.J. Yeasts from the north Sea. Mar. Biol., New York, 1, 118-123, 1967.

22. Meyers, S.P.; Ahearn, D.G., lmplications of yeasts and yeast-like fungi in marine Process. Veröff. Inst. Meeresforsch. Bremerhaven Suppl., 5, 321-338, 1974.

23. Morris, E.O. Yeasts of marine origin. Oceanogr. Mar. Biol. Ann. Rev., 6, 201-230, 1968.

24. Paula, C.R.; Purchio, A.; Gambale, W. Yeasts from beaches in the Southem Area of São Paulo state. "Baixada Santista", Brasil. Rev. Microbiol., São Paulo, 14(2), 136-143,1983.

25. Piontelli, E.; Toro, M.A. Yeasts communities in sandy soil (a beach of V Region, Chile) II, Bol. Micol., 2, 109-118, 1985.

26. Pinto, I.M. de A.; Cavalcanti, M.A.Q.; Passavante, J.Z. de O. Fungos filamentosos do solo e da água da praia de Boa Viagem, Recife-PE. Bol. Micol., 7(1-2), 39-45, 1992.

27. Queiroz, L.E. Análise Quanti - Qualitativa de leveduras isoladas de algas marinhas. I - Recife, Instituto de Micologia da Universidade Federal de Pernambuco, publ. 677, 1972. 